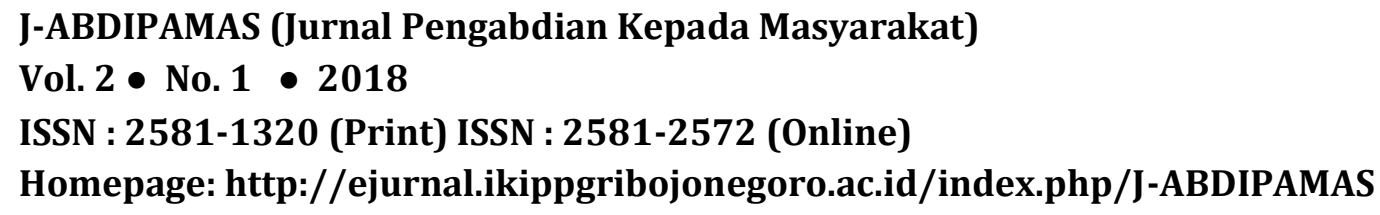

ISSN : 2581-1320 (Print) ISSN : 2581-2572 (Online)

Homepage: http://ejurnal.ikippgribojonegoro.ac.id/index.php/J-ABDIPAMAS

\title{
MEMBINA KELUARGA SEJAHTERA MELALUI PENERAPAN 8 FUNGSI KELUARGA
}

\author{
Arri Handayani ${ }^{1}$, Padmi Dhyah Yulianti ${ }^{2}$, Sukma Nur Ardini ${ }^{3}$ \\ 1 Universitas PGRI Semarang. Email: arrihandayani@upgris.ac.id \\ 2 Universitas PGRI Semarang. Email: yuli.dhy@gmail.com \\ 3 Universitas PGRI Semarang. Email: sukmanurardini27@gmail.com
}

\begin{abstract}
Prosperous family is the desire for every individual, but many influential factors to achieve the condition. One is how to implement 8 family functions. Many citizens who do not understand and do not even know about the 8 functions of the family itself. This is evidenced by the many problems that people complain about family problems. Whereas if the community can implement these functions, the existence of family problems can be minimized. This condition is known when the devotees conduct the counseling process in the "Pojok Konseling". Therefore, in community service activities conducted by the Team KKN PPM Kampung KB University of PGRI Semarang in the district Muktiharjo Kidul, Pedurungan, Semarang given counseling about the family function in an effort to foster a prosperous family. This activity was attended by 31 participants of the resident Muktiharjo Kidul Semarang through lecture and discussion methods. The results of the analysis through observation and feedback from the participants showed that the participants pleasured to gain knowledge and understanding to achieve prosperous family through the implementation of 8 family functions.
\end{abstract}

Keywords: prosperous family, 8 family functions.

\begin{abstract}
ABSTRAK
Keluarga sejahtera adalah dambaan bagi setiap individu, akan tetapi banyak faktor yang berpengaruh untuk dapat mencapai kondisi tersebut. Salah satunya adalah bagaimana menerapkan 8 fungsi keluarga. Banyak warga masyarakat yang belum memahami dan bahkan belum mengetahui tentang 8 fungsi keluarga tersebut. Hal ini terbukti dengan banyaknya masalah yang dikeluhkan masyarakat berkaitan dengan permasalahan keluarga. Padahal jika masyarakat dapat menerapkan fungsi-fungsi tersebut, adanya permasalahan keluarga dapat diminimalkan. Kondisi ini diketahui ketika pengabdi melakukan proses konseling di "Pojok Konseling". Oleh karena itu, dalam kegiatan pengabdian masyarakat yang dilakukan oleh Tim KKN PPM Kampung KB Universitas PGRI Semarang di Muktiharjo Kidul Kecamatan Pedurungan Semarang diberikan penyuluhan tentang fungsi keluarga dalam upaya membina keluarga sejahtera. Kegiatan ini diikuti oleh 31 peserta warga Muktiharjo Kidul Semarang melalui metode ceramah dan diskusi. Hasil analisis melalui observasi dan umpan balik dari peserta, menunjukkan bahwa peserta menunjukan rasa senang mendapatkan pengetahuan dan pemahaman untuk mencapai keluarga sejahtera melalui penerapan 8 fungsi keluarga.
\end{abstract}

Kata kunci: keluarga sejahtera, 8 fungsi keluarga.

\section{PENDAHULUAN}

Pada dasarnya setiap individu menginginkan keluarga yang sejahtera. Meskipun demikian, banyak faktor yang mempengaruhi pada tinggi rendahnya tingkat kesejahteraan seseorang. Dengan tercukupi kebutuhan matrial dan spiritual, seseorang dapat saja merasakan 
suatu kondisi sejahtera, dapat menikmati hidup secara wajar dan menyenangkan. Akan tetapi, kenyataannya tidak semuanya demikian. Pada suatu keluarga yang serba tercukupi kebutuhannya, sesungguhnya ada juga yang justru merasakan tidak sejahtera.

Dalam hal ini, menentukan apa arti yang sebenarnya dari sejahtera merupakan hal yang sulit untuk dilakukan. Kondisi ini terjadi karena setiap orang dalam suatu keluarga memiliki cara tersendiri dalam memaknai kesejahteraannya. Karena sejahtera itu bersifat subyektif, maka bisa jadi seperti yang telah dikatakan sebelumnya, bahwa walaupun tercukupi semua kebutuhan tetapi mungkin merasa tidak bahagia, dan sebaliknya walaupun dengan kondisi yang kurang mampu, tetapi justru merasa nyaman. Hal ini seperti dikatakan Surati (2013:57 ) bahwa persepsi masyarakat mengenai kesejahteraan juga berbeda-beda. Terdapat kelompok masyarakat (elite desa) yang menggunakan ukuran kesejahteraannya bersumber pada simbol kekuasaan budaya politik, sementara monetisasi ekonomi menghantarkan kalangan masyarakat pada umumnya untuk lebih menggunakan ukuran modern kesejahteraan lahirial dibandingkan ukuran kesejahteraan tradisional.

Menurut UU No 10 tahun 1992 yang diamandemen menjadi UU No 52 tahun 2009 tentang Perkembangan Kependudukan dan Pembangunan Keluarga Sejahtera menyebutkan bahwa keluarga sejahtera adalah keluarga yang dibentuk atas dasar perkawinan yang sah, mampu memenuhi kebutuhan hidup spiritual, dan material yang layak, bertaqwa kepada Tuhan Yang maha Esa, memiliki hubungan yang serasi, selaras dan seimbang antar anggota dan antara keluarga dengan masyarakat dan lingkungan. Sementara itu, menurut BKKBN pengertian keluarga sejahtera adalah keluarga yang dapat memenuhi kebutuhan anggotanya, baik kebutuhan sandang, pangan, perumahan, social dan agama; keluarga yang mempunyai keseimbangan antara penghasilan keluarga dengan jumlah anggota keluarga, keluarga yang dapat memenuhi kebutuhan kesehatan anggota keluarga, kehidupan bersama dengan masyarakat sekitar, beribadah khusuk disamping terpenuhinya kebutuahn pokok. Mengacu pada beberapa pendapat tersebut dapat dikatakan bahwa keluarga sejahtera adalah keluarga yang mampu memenuhi kebutuhan anggotanya secara minimal sesuai dengan persepsi anggota keluarga tersebut.

Menurut Ariati (2010 :117-123) faktor-faktor yang mempengaruhi kesejahteraan subjektif diantaranya adalah harga diri positif, kontrol diri, ekstraversi, optimis, relasi sosial yang positif serta memiliki arti dan tujuan dalam hidup. Sementara itu menurut (Diener e al., 2003 :403-425), faktor demografi seperti kesehatan, penghasilan, dan latar belakang pendidikan juga mempengaruhi kesejahteraan subyektif seseorang. Menurut Maika (2009:34), faktor-faktor yang dapat memengaruhi kebahagiaan di antaranya adalah aspirasi dan harapan hidup serta bagaimana cara mereka mencapainya.

Kondisi keluarga yang tidak sejahtera ini pengabdi ketahui ketika melakukan proses konseling di "Pojok Konseling". Beberapa warga datang kepada pengabdi mengemukakan permasalahanya berkaitan dengan kondisi keluarga. Dari beberapa klien yang datang memang tampak berasal dari keluarga menengah ke bawah, yang berarti mereka berada pada tingkat ekonomi yang rendah. Akan tetapi beberapa klien yang lain, secara fisik dan penampilan menunjukkan bahwa mereka berasal dari keluarga yang mampu. Dengan demikian, jelas bahwa tanpa pandang bulu, mereka berasal dari masyarakat menengah ke bawah ataupun masyarakat yang secara ekonomi lebih mapan dapat mengalami permasalahan keluarga.

Ketika pengabdi mengekplorasi permasalahan klien lebih dalam, sebagian besar permasalahan terjadi karena klien belum sepenuhnya menerapkan fungsi-fungsi sebagai sebuah keluarga. Padahal memasuki kehidupan berkeluarga tentunya memerlukan persiapan yang matang dari setiap pasangan dalam membangun keluarga yang harmonis dengan melaksanakan 8 fungsi keluarga. Dalam setiap fungsi keluarga terdapat nilai-nilai moral yang harus diterapkan 
dalam keluarga seperti fungsi agama, sosial budaya, cinta dan kasih sayang, perlindungan, reproduksi, sosialisasi dan pendidikan, ekonomi, dan fungsi lingkungan.

Menghadapi situasi demikian, maka pengabdi merasa perlu melakukan penyuluhan tentang bagaimana membina keluarga sejahtera melalui penerapan 8 fungsi keluarga. Penyuluhan ini dilaksanakan di Kelurahan Muktiharjo Kidul Kecamatan Pedurungan Semarang mengingat masih banyak masyarakat yang merasa belum memahami bahwa keluarga mempunyai fungsi penting dalam upaya mencapai kesejahteraannya. Sebagian sudah ada yang mengetahui, walaupun tidak mengetahui secara detail, akan tetapi sebagian lagi ada yang tidak peduli bahwa kesejahteraan keluarga itu justru dibangun dari keluarga itu sendiri.

Oleh karena itu, kegiatan pengabdian masyarakat yang diselenggarakan oleh tim KKN PPM Kampung KB Universitas PGRI Semarang ini akan memberi penyuluhan tentang bagaimana membina keluarga sejahtera melalui penerapan 8 fungsi keluarga.

\section{METODE PELAKSANAAN}

Penyuluhan tentang bagaimana membina keluarga sejahtera melalui penerapan 8 fungsi keluarga diberikan dengan tujuan untuk memberikan pemahaman kepada masyarakat tentang pentingnya peran keluarga. Kegiatan ini dilaksanakan pada tanggal 26 Agustus 2017 pk 15.30-17.30 di Balai kelurahan Muktiharjo Kidul Pedurungan Semarang, dan diikuti oleh 31 peserta.

Metode yang digunakan untuk menyelesaikan masalah dengan menggunakan ceramah dan diskusi. Selanjutnya hasil analisis melalui observasi dan umpan balik dari peserta, menunjukkan bahwa peserta menunjukan rasa senang mendapatkan pengetahuan dan pemahaman untuk mencapai keluarga sejahtera melalui penerapan 8 fungsi keluarga.

\section{HASIL DAN PEMBAHASAN}

Penyuluhan membina keluarga sejahtera melalui penerapan 8 fungsi keluarga merupakan salah satu dari program KKN PPM Kampung KB Universitas PGRI Semarang di Kelurahan Muktiharjo Kidul Kecamatan Pedurungan Semarang. Melalui kegiatan ini warga Muktiharjo Kidul merasa mempunyai pengetahuan dan pemahaman tentang pentingnya peran keluarga untuk membina keluarga sejahtera. Berikut petikan wawancara dengan salah satu peserta.

"Kami merasa senang bisa hadir dalam kegiatan ini. Walaupun pada awalnya saya merasa ogah-ogahan datang, tetapi ketika sudah di sini dan mendapatkan materi ini, saya merasa lebih memahami tentang pentingnya peran keluarga. Apalagi saya punya anak remaja, yang susah dikendalikan, sehingga dengan datang ke acara ini, saya merasakan betul manfaatnya.

Berdasarkan hasil petikan wawancara tersebut diketahui bahwa masyarakat merasakan betul manfaat dari kegiatan ini. Apalagi dengan adanya anak remaja yang butuh "sentuhan" khusus dari orang tua.

Sementara itu, kelemahan dari kegiatan penyuluhan ini adalah masalah waktu. Kegiatan dilaksanakan sebelum sholat ashar, sehingga dalam prakteknya harus mundur beberapa saat, karena menunggu peserta hadir untuk melaksanakan sholat. Peserta yang hadir, juga hanya 50\% dari target peserta, karena ketika mengundang sepasang suami istri, pada umnya yang hadir hanya satu orang saja. 
Oleh karena itu, mengacu pada hal-hal tersebut di atas, dapat disampaikan saransaran sebagai berikut :

a. Kegiatan akan lebih baik jika dilaksanakan pada hari Minggu, atau pada hari para warga mengadakan pertemuan, seperti pertemuan PKK, ataupun arisan bapakbapak.

b. Jika ingin memberikan pemahaman kepada kedua belah pihak suami istri, ada baiknya masing-masing diundang sendiri-sendiri. Karena ketika mereka berdua diundang bersama-sama, kemungkinan hadir berdua adalah kecil, apalagi pada keluarga yang masih mempunyai anak balita.

Berikut adalah foto-foto tentang kegiatan tersebut.

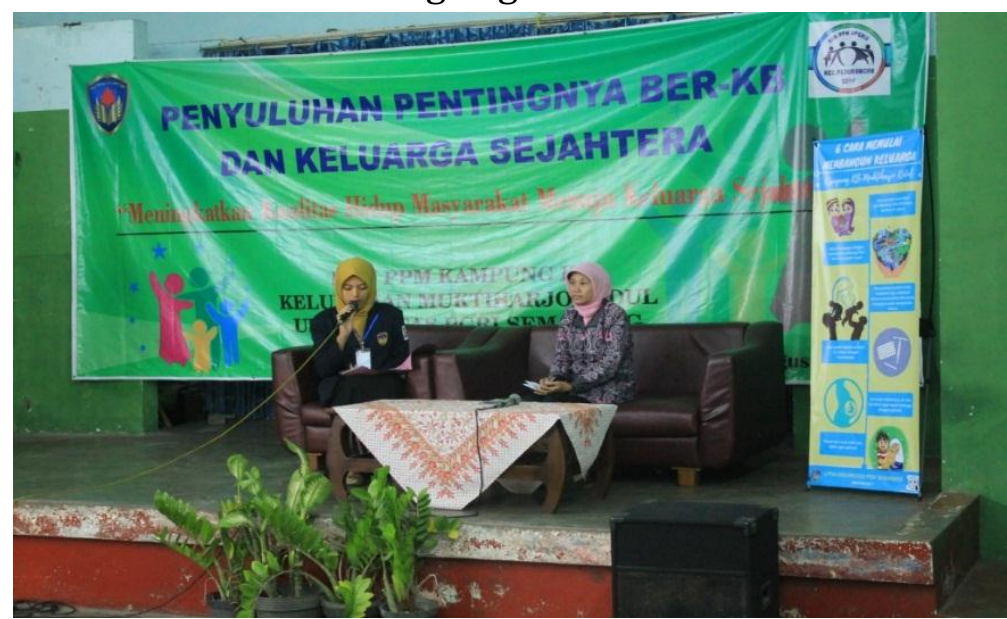

Gambar 1. Pemateri bersama moderator akan melalukan pemaparan

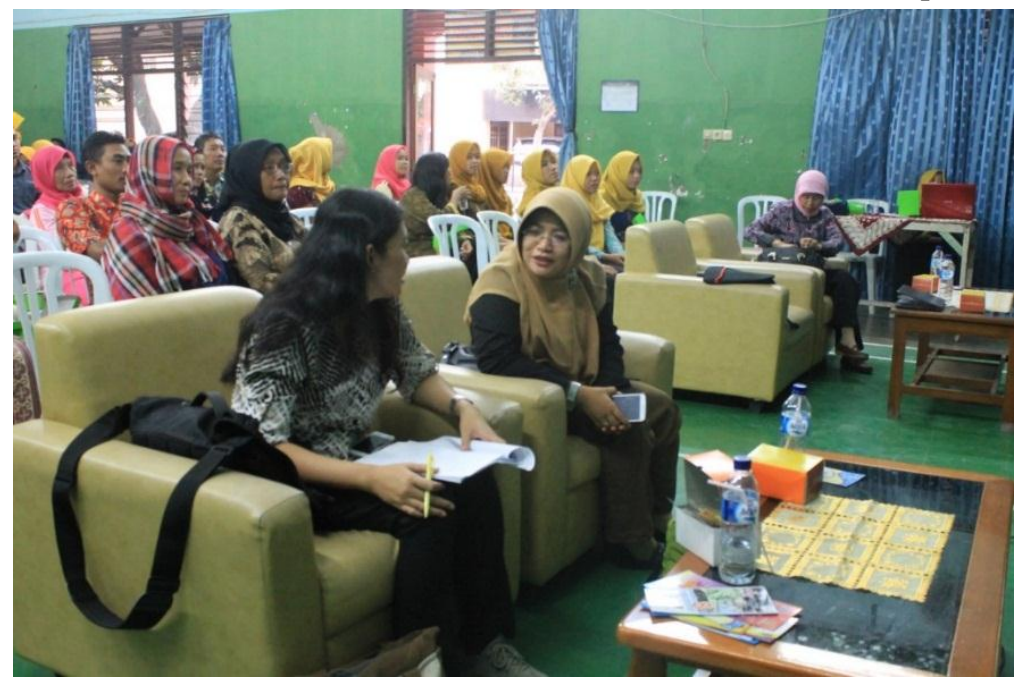

Gambar 2. Peserta dengan antusias memperhatikan

\section{SIMPULAN}

Berdasarkan pelaksanaan kegiatan pengabdian masyarakat oleh TIM KKN PPM Kampung KB Universitas PGRI Semarang yaitu penyuluhan membina keluarga sejahtera melalui penerapan 8 fungsi keluarga dapat diuraikan beberapa kesimpulan sebagai berikut: (a) Kegiatan penyuluhan keluarga sejahtera berlangsung dengan baik, (b) Kegiatan penyuluhan keluarga sejahtera dirasakan banyak memberi manfaat bagi Masyarakat, (c) Kegiatan penyuluhan keluarga sejahtera ataupun penyuluhan tentang 
keluarga semacam kegiatan parenting perlu diagendakan sebagai kegiatan rutin, dengan membangun jaringan kerja sama antara pemerintah daerah dengan Universitas PGRI Semarang, khususnya LPPM melalui Pusat Kependudukan Perempuan dan Perlindungan Anak.

\section{DAFTAR RUJUKAN}

Ariati, J. (2010). Subjective well-being (kesejahteraan subjektif) dan kepuasan kerja pada staf pengajar (dosen) di lingkungan fakultas psikologi universitas diponegoro. Jurnal Psikologi Undip, 8, 2, 117-123.

Diener, E. (2003). Findings on well being and their implications for empowerment. Paper presented at the workshop on "Measuring Empowerment: Cross Disciplinary Perspectives" held at the World Bank in Washington DC, on February 4 and 5, 2003. http://siteresources.worldbank.org/INTEMPOWERMENT/Resources/4863 12-095970750368/5297631095970803335/diener.pdf, diakses tanggal 13 Mei 2015.

Diener, E. Oishi, S. \& Lucas, R. E. (2003). Personality culture, and subjective well-being: Emotional and cognitive evaluation of life. Annual Review of Psychology, 54, 403 425.

Direktorat Pemaduan Kebijakan Pengendalian Penduduk. BKKBN. Policy Brief, KB solusi cerdas dalam memutus kemiskinan perempuan di Indonesia. Jakarta : BKKBN.

Maika, A. (2009). Mengukur Kemiskinan Subjektif di Indonesia: Eksplorasi Faktor yang Membuat Seseorang Merasa Miskin. Center for Population and Policy Studies Gadjah Mada University.

Surati, E. (2013) Kependudukan dan Keluarga Sejahtera. Isu strategis adalam analisa dampak kependudukan terhadap aspek sosial ekonomi. Dalam Direktorat Analisis Dampak Kependudukan BKKBN. 